\title{
Modernity and Regionalism in Pernambuco's Design: Lula Cardoso Ayres
}

Lula Cardoso Ayres was the modern artist and designer who best visually reproduced Gilberto Freyre's regionalistic theories. This paper discusses how his different activities within the production of symbolic goods in Pernambuco are visually manifested in his graphic design.

\section{Introduction}

Recife, the capital of Pernambuco, in Northeast of Brazil, was going through expressive social, political, economic and urbanistic transformations in the beginning of the zoth century, especially as from the 1920s. These transformations were also revealed in the intellectual and artistic fields through the opposition between modernists and regionalists - the latter led by Gilberto Freyre. Lula Cardoso Ayres, visual artist, graphic designer between the 1940 s and the 1970 - and teacher, was who best visually manifested in his work Freyre's regionalist ideals.

Considering that aesthetic choices are umbilically tied to the social agent's actions in the social space and to the habitus, in the sense elaborated by Pierre Bourdieu (2005), the research problem of this paper consists in identifying how the aesthetic dispositions (the taste) of Lula Cardoso Ayres were visually manifested in his Graphic Design pieces through his action's strategies within the erudite artistic field, the educational system and the cultural industry field.

The general objective is to redeem Lula Cardoso Ayres' graphic design works, taking into account its symbolic capital and the position of the Design in his work as a whole. The specific objectives are: to establish correlations between his works of art and his graphic design works; to promote the appreciation of Pernambuco's graphic memory; through the joint effort with several collections of the Recife city, to make public the abundance of research material owned by those institutions, encouraging thus new historical researches.

The justification of this research is found in Ayres as a pioneer in the field of Design in Pernambuco, since he was one of the few renowned artists in the State to regularly dedicate himself to the design activity - he worked for approximately thirty years in the Brazilian Graphic Industry (IGB) - and had an intimate relation with Gilberto Freyre's regionalistic, traditionalistic theories, which helped him to establish a modern aesthetic in Pernambuco's Design and to search for an Northeastern identity in his works. 
The research methodology consisted of bibliographic revision - having Pierre Bourdieu and Gilberto Freyre as theoretical marks -, open interviews with nine social actors (among them: three designers, two college teachers, one visual artist, one intellectual, one gallerist and one of Lula Cardoso Ayres' sons, who administered an institute named after his father) and iconographic research in private and public collections - being the latter: Joaquim Nabuco Foundation, Public Library of the State of Pernambuco and National Public Library of Rio de Janeiro.

\section{Artistic Modernity in Pernambuco}

Recife, the capital of Pernambuco, in Northeast of Brazil, was going through expressive social, political, economic and urbanistic transformations in the beginning of the 2oth century, especially as from the 1920s. The agricultural economy based on sugarcane plantations was deteriorating while the region's industrial production was still incipient. With the sugarcane mills' collapse, the rural workers, mostly blacks and mulattos, vie through their shanties with the whites' mansions for the urbane space. At the same time, old colonial buildings were demolished in the name of the progress of modernity. The political tensions grew bigger between the representatives of the decadent sugarcane elite and the coffee farmers' oligarchy from the Southeast.

Gilberto Freyre, author of The Master and the Slaves, representing the first group's interests, defended the permanence of the traditional values related to the sugarcane elite, the popular manifestations and the miscegenation of races as fundamental element of Brazilian national identity. The preservation of the historic patrimony, of the native fauna and flora and the defense of the regional cuisine as "fraternization" of the three ethnicities (white, black and Indian) are examples of the guidelines upheld by Recife's Regionalist, Traditionalist and, in its way, Modernist Movement.

The opposition to Gilberto Freyre's regionalists' group was led by the journalist Joaquim Inojosa, responsible for divulgating in Pernambuco the modernism of the Week of Modern Art of 1922. However, "Joaquim Inojosa's understanding of the modernism went never beyond its exterior, formal aspect, of a 'futuristic' iconoclasm" (Teixeira 2007:67), concerned only with the destruction of old symbols and traditions.

Even with the quarrels between regionalists and modernists, Freyre did not repudiate the modernity. To him, the modernity would be the conjunction between the traditional and the regional with elements of an extern origin, being this heteronomous element filtrated and resized so that there was no damage to the traditional and regional elements, be it in cuisine, architecture, politics or visual arts. Freyre's modernity does not recognize itself within the modernism though, for the latter is the crystallization of a moment, losing its revolutionary power. To Freyre (1987), art should not close itself inside formalisms and forget about the fertile social and ecological context in which it is found and with which the artist does not need to fear to be involved to develop his creativity.

Among these artists who do not close themselves in aesthetic preciosities, who experiment and renew when uniting the regional, the erudite, the popular, the traditional, who are moderns, but not modernists, Lula Cardoso Ayres is who best visually represents those ideas. Visual artist, muralist, scenographer, he also dedicated himself for nearly thirty years to the graphic design field, covering a period of time when the aesthetic hegemonic norm of that activity came from European countries and the higher educational system of Design in Brazil was implemented. 


\section{Lula Cardoso Ayres: designer}

The ideals of preservation of the traditional and regional values, organized in Recife's Regionalist, Traditionalist and, in its way, Modernist Movement, found their best visual manifestation in the work of the visual artist Lula Cardoso Ayres, who worked as graphic designer between the 1940 s and the 1970 s at the same time that was producing canvas and murals and was teaching in the School of Fine Arts of Pernambuco.

Lula Cardoso Ayres was born in 1910 in Recife. His father, João Cardoso Ayres, was called King of Sugar due to the production of his sugarcane mill. As a sick child, Lula devoted himself to art. At twelve years old, he had illustrations published in a Recife newspaper and was influenced by his cousin, the caricaturist Emílio Cardoso Ayres, who died at the time of the World War I.

Also at twelve, he becomes an assistant of the architect, stained-glass artist and one of the founders of the School of Fine Arts of Pernambuco, Heinrich Moser. With him, Ayres learnt high methodological rigorousness, to keep control of the whole production process, from how to clean the brush until the execution of the work. Moser was "one of those useful and universal artists" (Cláudio 1982: 13), who personally undertook from the project's conception until its execution.

At fifteen, he travelled to Paris where he had contact with the European Modernism and was student of the Symbolist Maurice Denis, who defended the point of view that a painting is, first of all, ink applied on a support, highlighting thus the importance of the knowledge about painting techniques.

Back to Brazil, with approximately eighteen years old, he was student of Carlos Chambelland, in Rio de Janeiro. Chambelland was a painter, decorator and enthusiast of the artistic research about popular and land related motifs. He was probably the one who introduced the young Lula in the pursuit of a truly Brazilian painting, also a concern to the modernists of the 1922 Week of Modern Art, some with whom Lula came to keep contact. Among them, Cândido Portinari, who assiduously frequented the studio that Ayres' father had fitted up for him. Still in Rio de Janeiro, the young artist projected the sceneries, furniture and all the decoration for the plays "O Segredo de Próspero" and "A Última Conquista", respectively by Procópio Ferreira and Renato Vianna. "It was an all-inclusive work of an environmental art, looking at all details, including the equated confection of furniture and decoration" (Valladares 1979: 18).

In 1930, at twenty, he created with Wily Lewin the magazine P'ra Você in Recife. With evident influences of Art Deco, Lula was a cover artist and illustrator for a year. Still in 1930, he began to collaborate in Rio de Janeiro's magazine Para Todos. In the following year, he moved to Rio to be one of the substitutes of the famous J. Carlos. Illustrations of blacks and mulattos, of Rio's typical characters, of banana plants and tropical fruits are common in Ayres' production in Para Todos, which was not frequently seen in P'ra Você; a rehearsal of what would follow in his artistic work.

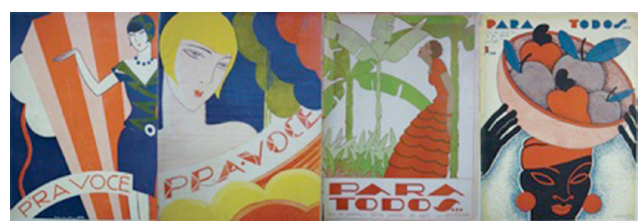

Figure 1,

Lula Carodoso Ayres's covers. In order: P'ra Você (1930) ed. 7-14; Para Todos (1932), ed. 685-695. 
theme 2

memory

Figure 2.

Lula Cardoso Ayres' paintings. In order: Cutting the cake (1940); The Frevo (1945); Xangô (1950's). strand 1

design histories: tradition, transgression and transformations

With high symbolic capital due to his professional success in Rio de Janeiro and with technical knowledge of printing, he came back to Recife and participated in the First Afro-Brazilian Congress, organized by Gilberto Freyre in 1934, with illustrations of xangôs of Pina neighborhood, guided by the poet and folklorist Ascenço Ferreira. This return to hometown happened by his father's request to help in the administration of the decadent sugarcane mill. Without tact for administration, Lula fits up a studio in the mill. At that time, Lula Cardoso Ayres starts the work of a "visual anthropologist", recording, through photographs and realistic drawings, the rural workers, the Fulni-ô tribe's Indians and several popular manifestations like the dances bumba-meu-boi, maracatu and caboclinhos throughout the countryside.

From this dive into people's reality, he emerges as a mature artist in 1945 with his paintings about the earthen dolls, with new aesthetic expression, modernly regional and universal, as Freyre would proclaim. His geometry then did not allude anymore to a commercial graphic fad from when he was a cover designer and illustrator, but arose from the composition of what he saw, what he felt. It was in his works' structure and surface. Cubist influence, but nothing that jeopardizes his originality.

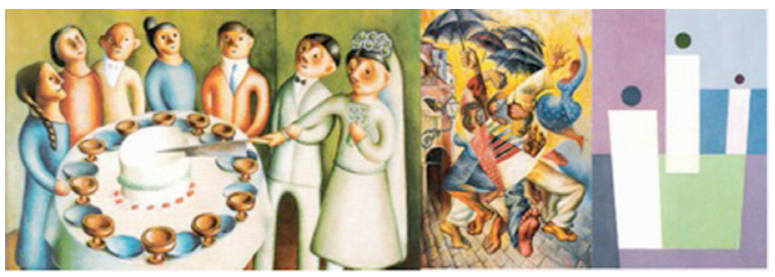

This formal depuration is brought to his design. Also in 1945, after his father's mill's bankruptcy, Ayres is invited by the Dreschler brothers to work in the Brazilian Graphic Industry, the biggest Northeastern printing house at the time. With the technical knowledge about printing acquired in Rio the Janeiro and applying his artistic abilities at the service of the middle-brow art field, Lula projects memorable works, some in use today with small variations. Also at that time, he is invited to teach at the School of Fine Arts of Pernambuco, facing the classical academicians. As a painter, he is acclaimed as modern due to his murals; modern art since integrative of painting and architecture.

It is noticed thus that Ayres transited in the erudite field (as artist and teacher) and in the cultural industry (as designer) with complete identification with Freyre's regionalistic values. One may think therefore that his design is indebted to his activity as an artist, that he would apply the style of one of his artistic periods in his design. However, Ayres shows to be capable of identifying the problem, creating alternatives and choosing the best solution independently of what he accomplishes in painting. When projecting the first piece of the figure 3, Lula was in the abstract phase that began approximately in 1950 and lasted for ten years.

Even adopting the geometry, like in the brand Bem-Te-Vi, and the geometrical abstractionism, like in the packages of the biscuits Confiança above - his most famous projects - , his logic was completely different of the International Style. His adherence to a universal language is prior and derived of another source. His source was the relation between man and land, basic and primordial relationship, captured through the rural workers, the popular cultural manifestations, and visually transformed into compositions and universal forms, containing high communicative power in his pieces. 


\section{Conclusion}

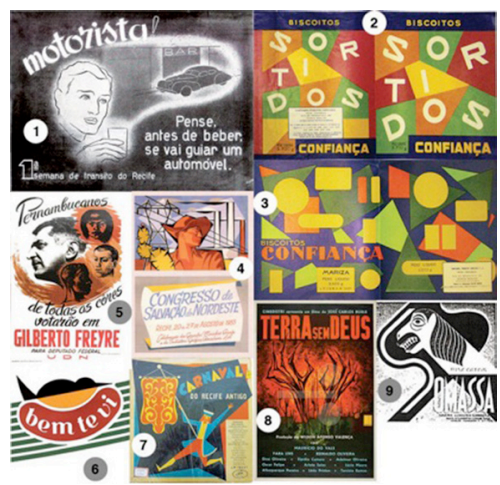

Engulfed by the spirit of the time, of a modernity that did not relegated traditional and regional values, from illustrator to artist, teacher, scenographer, muralist and designer, Lula Cardoso Ayres was modern through the themes, forms, technical experiments and of support, for not closing himself inside "isms", for not crystallizing himself in one aesthetics, always changing, researching, diving into the telluric reality of Northeastern people. His designs were not tied to his art, but had enormous strength and appeal to the point of remaining in use or being remembered for decades, highlighting his work's value to the graphic memory of Pernambuco and of the Northeast.

Lula Cardoso Ayres, designer. Modernly regional aesthetics of Pernambuco's graphic design. Not a modernist designer with tropical taste, enchanted by exoticism. Not an outsider observer making use of a popular language to merely reapply it in others artifacts, emptying its forms of content. Ayres lived, experienced, assumed the Northeastern people's reality as his own. He made it his art, his design. Aristocratically educated, habitually connected to the conservative party, he knew how to transit amongst different political groups, captivating friendships. Foes within the Academy. With Germanic education, he was recreated by the ceramics' clay. Bumba-meu-boi's bluish nights filling up his mind with popular symbols. The Carnival vibrating in his body, his brushes, his murals, his scenographies and his serigraphs. Lithographs. Offset. Illustrations, first attempts into the popular. Tomorrow's master. Master from the past that deserves to be redeemed.

Perhaps Ayres did not see himself as a designer. That valorization has been given lately, umbilically connected to his legitimacy as an artist. Some interviewees, when asked what they thought about Ayres' work as a designer, hesitated and answered based on their knowledge of his artistic work. "Everyone always respected Lula very much. I never saw anyone speaking evil of Lula. Everyone respected him for his production, for his work, for the work as a whole" (Lima 2010). Complete, integrative. Not only his painting was integrative; but in his way of being an artist, everything for him was his art, even the design.

\section{References}

Bourdieu, P. (2005) A Economia das Trocas Simbólicas. 6.ed. São Paulo: Perspectiva (Estudos Collection)

Claudio, J. (1982) Artistas de Pernambuco. Recife: State Government.

Freyre, G. (1987) Vida, forma e cor. 2. ed. Rio de Janeiro: Record, 1987. 
theme 2

memory strand 1

design histories: tradition, transgression and transformations

LIMA, M. (2010) Interview at her house on 1th December. In: LIMA, R. (2011) Estética moderna do design pernambucano: Lula Cardoso Ayres. Recife: Federal University of Pernambuco. Master thesis. $137 \mathrm{p}$.

Teixeira, F. (2007) O movimento e a linha: presença do Teatro do Estudante e d' O Gráfico Amador no Recife (1946 - 1964). Recife: University Press - UFPE. 